\title{
MYC, FBXW7 and TP53 copy number variation and expression in Gastric Cancer
}

\author{
Danielle Queiroz Calcagno ${ }^{1,2^{*}}$, Vanessa Morais Freitas ${ }^{3}$, Mariana Ferreira Leal ${ }^{2}$, Carolina Rosal Teixeira de Souza', \\ Samia Demachki ${ }^{4}$, Raquel Montenegro ${ }^{1}$, Paulo Pimentel Assumpção ${ }^{5}$, André Salim Khayat ${ }^{1}$, \\ Marília de Arruda Cardoso Smith ${ }^{2}$, Andrea Kely Campos Ribeiro dos Santos ${ }^{6}$ and Rommel Rodriguez Burbano ${ }^{1}$
}

\begin{abstract}
Background: MYC deregulation is a common event in gastric carcinogenesis, usually as a consequence of gene amplification, chromosomal translocations, or posttranslational mechanisms. FBXW7 is a p53-controlled tumor-suppressor that plays a role in the regulation of cell cycle exit and reentry via MYC degradation.

Methods: We evaluated MYC, FBXW7, and TP53 copy number, mRNA levels, and protein expression in gastric cancer and paired non-neoplastic specimens from 33 patients and also in gastric adenocarcinoma cell lines. We also determined the invasion potential of the gastric cancer cell lines.

Results: MYC amplification was observed in 51.5\% of gastric tumor samples. Deletion of one copy of FBXW7 and TP53 was observed in $45.5 \%$ and $21.2 \%$ of gastric tumors, respectively. MYC mRNA expression was significantly higher in tumors than in non-neoplastic samples. FBXW7 and TP53 mRNA expression was markedly lower in tumors than in paired non-neoplastic specimens. Moreover, deregulated MYC and FBXW7 mRNA expression was associated with the presence of lymph node metastasis and tumor stage III-IV. Additionally, MYC immunostaining was more frequently observed in intestinal-type than diffuse-type gastric cancers and was associated with MYC mRNA expression. In vitro studies showed that increased MYC and reduced FBXW7 expression is associated with a more invasive phenotype in gastric cancer cell lines. This result encouraged us to investigate the activity of the gelatinases MMP-2 and MMP-9 in both cell lines. Both gelatinases are synthesized predominantly by stromal cells rather than cancer cells, and it has been proposed that both contribute to cancer progression. We observed a significant increase in MMP-9 activity in ACP02 compared with ACP03 cells. These results confirmed that ACP02 cells have greater invasion capability than ACP03 cells.
\end{abstract}

Conclusion: In conclusion, FBXW7 and MYC mRNA may play a role in aggressive biologic behavior of gastric cancer cells and may be a useful indicator of poor prognosis. Furthermore, MYC is a candidate target for new therapies against gastric cancer.

Keywords: Gastric cancer, MYC, FBXW7, TP53

\section{Background}

Gastric cancer (GC) is the fourth most common cancer and the second leading cause of cancer death worldwide [1]. GC is considered a major public health concern, especially in developing countries, including Brazil [2].

\footnotetext{
* Correspondence: danicalcagno@gmail.com

'Laboratório de Citogenética Humana, Instituto de Ciências Biológicas, Universidade Federal do Pará, Belém, PA, Brasil

2Disciplina de Genética, Departamento de Morfologia e Genética, Escola Paulista de Medicina, Universidade Federal de São Paulo, Rua Botucatu 740, CEP 04023-900, São Paulo, SP, Brazil

Full list of author information is available at the end of the article
}

A fundamental aspect of carcinogenesis is uncontrolled cell proliferation resulting from the accumulation of changes that promote the expression or repression of cell cycle-control genes [3]. MYC is a transcriptional factor involved in cell cycle regulation and cell growth arrest that is commonly deregulated in cancers and has been described as a key element of gastric carcinogenesis $[4,5]$. Several different types of posttranslational modifications of MYC have been described, including phosphorylation, acetylation, and ubiquitination [6]. The ubiquitin-proteasome system is the major protein degradation regulatory pathway involved in cell differentiation

\section{Biomed Central}


and growth control [7]. FBXW7 encodes an F-box protein subunit of the Skp1/Cul1/F-box complex (SCF) ubiquitin ligase complex. $\mathrm{SCF}^{\mathrm{FBXW7}}$ induces degradation of the products of positive cell cycle regulator genes, such as cyclin E, MYC, NOTCH, and JUN, through phosphorylationdependent ubiquitination [8]. Among $\mathrm{SCF}^{\mathrm{FBXW} 7}$ substrates, MYC is of particular importance in cell cycle exit because it is thought to play a role in determining whether mammalian cells divide or not [9].

Deregulated $F B X W 7$ expression is a major cause of carcinogenesis [10-12]. Loss of FBXW7 expression can lead to MYC overexpression and has been associated with poor prognosis in GC patients [13]. However, MYC activation by $F B X W 7$ loss triggers activation of p53, which plays a key role in the regulation of cellular responses to DNA damage and abnormal expression of oncogenes. Induction of cell cycle arrest by p53 allows for DNA repair or apoptosis induction [14]. Thus, concomitant loss of FBXW7 and TP53 is necessary to induce genetic instability and tumorigenesis [11].

In the present study, we investigated $M Y C, F B X W 7$, and TP53 gene copy number variation and mRNA and protein expression in GC samples and gastric adenocarcinoma cell lines. Possible associations between our findings and the clinicopathological features and/or invasion and migration capability of the cell lines were also evaluated.

\section{Methods}

\section{Clinical samples}

Samples were obtained from 33 GC patients who underwent surgical treatment at the João de Barros Barreto University Hospital in Pará State, Brazil. Dissected tumor and paired non-neoplastic tissue specimens were immediately cut from the stomach and frozen in liquid nitrogen until RNA extraction.

The clinicopathological features of the patient samples are shown in Table 1. GC samples were classified according to Lauren [15]. All GC samples showed the presence of Helicobacter pylori, and the cagA virulence factor was determined by PCR analysis of ureA and cagA as described by Clayton et al. [16] and Covacci et al. [17], respectively. All patients had negative histories of exposure to either chemotherapy or radiotherapy before surgery, and there were no other co-occurrences of diagnosed cancers. Informed consent with approval of the ethics committee of the Federal University of Pará was obtained.

\section{Cells lines}

Gastric adenocarcinoma cell lines ACP02 and ACP03 [18] were cultured in complete RPMI medium (Invitrogen Corp., Carlsbad, CA, USA) supplemented with 10\% fetal bovine serum (FBS), 1\% penicillin/streptomycin, and 1\% kanamycin.

\section{Copy number variation (CNV)}

DNA was extracted using a DNAQiamp mini kit (Qiagen, Hilden, Germany) according to the manufacturer's instructions. Duplex quantitative real-time PCR (real-time qPCR) was performed using the FAM/MGB-labeled TaqMan probes for MYC (Hs01764918_cn), FBXW7 (Hs01362464_cn), or TP53 (Hs06423639_cn), and VIC/ TAMRA-labeled TaqMan CNV RNAse P (\#4403326) was used for the internal control. All real-time qPCR reactions were performed in quadruplicate with gDNA according to the manufacturer's protocol using a 7500 Fast Real-Time PCR system (Life Technologies, Foster City, CA, USA). The copy number of each sample was estimated by CNV analysis using Copy Caller Software V1.0 (Life Technologies, Foster City, CA, USA). Known Human Genomic DNA (Promega, Madison, USA) was used for calibration.

\section{Quantitative real-time reverse transcriptase PCR}

Total RNA was extracted with TRI Reagent ${ }^{\circ}$ Solution (Life Technologies, Carlbad, CA, USA) following the manufacturer's instructions. RNA concentration and quality were determined using a NanoDrop spectrophotometer (Thermo Scientific, Wilmington, DE, USA) and $1 \%$ agarose gels. Complementary DNA (cDNA) was synthesized using a High-Capacity cDNA Archive kit according to the manufacturer's recommendations (Life Technologies, Foster City, CA, USA). Real-time qPCR primers and TaqMan probes targeting $M Y C$ (Hs00153408_m1), FBXW7 (Hs00217794_m1), and TP53 (Hs01034249_m1) were purchased as Assays-on-Demand Products for Gene Expression ((Life Technologies, Foster City, CA, USA). Real time qPCR was performed using an ABI Prism 7500 system (Life Technologies, Foster City, CA, USA) according to the manufacturer's instructions. GAPDH (NM_002046.3; Life Technology, USA) was selected as an internal control for monitoring RNA input and reverse transcription efficiency. All real-time qPCR reactions for target genes and internal controls were performed in triplicate on the same plate. The relative quantification (RQ) of gene expression was calculated using the $\Delta \Delta \mathrm{Ct}$ method [19], in which the non-neoplastic sample was designated as a calibrator for each paired tumor sample.

\section{Immunohistochemistry}

Immunohistochemical analyses for MYC and p53 were performed on formalin-fixed, paraffin-embedded surgical sections. Serial $3-\mu \mathrm{m}$ sections were used. Heat-induced antigen retrieval was employed (microprocessor-controlled pressure Pascal ${ }^{\circ}$ DakoCytomation, Carpinteria, CA, USA). A universal peroxidase-conjugated secondary antibody kit 
Table 1 MYC, FBXW7 and TP53 gene copy number variation, MYC and p53 protein expression and clinicopathological features of 33 GC patients

\begin{tabular}{|c|c|c|c|c|c|c|c|c|c|c|c|c|c|c|c|}
\hline & \multicolumn{3}{|c|}{ CNV MYC } & \multicolumn{2}{|c|}{ CNV FBXW7 } & \multirow[b]{2}{*}{$p$-value } & \multicolumn{2}{|c|}{ CNV TP53 } & \multirow[b]{2}{*}{$p$-value } & \multicolumn{3}{|c|}{ IHC MYC } & \multicolumn{3}{|c|}{ IHC p53 } \\
\hline & $\begin{array}{l}2 \text { copies } \\
(n=16)\end{array}$ & $\begin{array}{c}\geq 3 \text { copies } \\
(n=17)\end{array}$ & $p$-value & $\begin{array}{l}2 \text { copies } \\
(n=18)\end{array}$ & $\begin{array}{c}1 \text { copy } \\
(n=15)\end{array}$ & & $\begin{array}{l}2 \text { copies } \\
(n=25)\end{array}$ & $\begin{array}{l}1 \text { copy } \\
(n=7)\end{array}$ & & $P(n=19)$ & $N(n=14)$ & $p$-value & $P(n=6)$ & $N(n=25)$ & $p$-value \\
\hline \multicolumn{16}{|c|}{ Age $(y)($ mean \pm SD) } \\
\hline$>50(65.3 \pm 9.1)$ & 7 & 12 & 0.166 & 12 & 7 & 0.304 & 15 & 3 & 0.393 & 10 & 4 & 0.310 & 5 & 9 & 0.094 \\
\hline$\leq 50(42.1 \pm 8.2)$ & 9 & 5 & & 6 & 8 & & 10 & 4 & & 10 & 9 & & 2 & 17 & \\
\hline \multicolumn{16}{|l|}{ Gender } \\
\hline Male & 8 & 7 & 0.437 & 7 & 8 & 1.000 & 13 & 1 & 0.104 & 12 & 3 & 0.072 & 2 & 13 & 0.413 \\
\hline Female & 8 & 10 & & 8 & 10 & & 12 & 6 & & 8 & 10 & & 5 & 13 & \\
\hline \multicolumn{16}{|l|}{ Histopathology } \\
\hline Intestinal & 12 & 10 & 0.465 & 12 & 10 & 1.000 & 16 & 6 & 0.387 & 17 & 5 & $0.009^{*}$ & 6 & 16 & 0.378 \\
\hline Diffuse & 4 & 7 & & 6 & 5 & & 9 & 1 & & 3 & 8 & & 1 & 10 & \\
\hline \multicolumn{16}{|c|}{ Depth of tumor invasion } \\
\hline $\mathrm{T} 1$ & 3 & 3 & 1.000 & 5 & 1 & 0.186 & 5 & 1 & 1.000 & 2 & 4 & 0.182 & 1 & 5 & 1.000 \\
\hline $\mathrm{T} 2-\mathrm{T} 4$ & 13 & 14 & & 13 & 14 & & 20 & 6 & & 18 & 9 & & 6 & 21 & \\
\hline \multicolumn{16}{|c|}{ Lymph node metastasis } \\
\hline Absent & 5 & 8 & 0.481 & 8 & 5 & 0.722 & 10 & 3 & 1.000 & 7 & 6 & 0.717 & 2 & 11 & 0.676 \\
\hline Present & 11 & 9 & & 10 & 10 & & 15 & 4 & & 13 & 7 & & 5 & 15 & \\
\hline \multicolumn{16}{|l|}{ Stage } \\
\hline$|-| \mid$ & 8 & 10 & 0.732 & 12 & 6 & 0.170 & 14 & 3 & 0.678 & 12 & 6 & 0.493 & 3 & 15 & 0.674 \\
\hline III-IV & 8 & 7 & & 6 & 9 & & 11 & 4 & & 8 & 7 & & 4 & 11 & \\
\hline \multicolumn{16}{|l|}{ MYC IHC } \\
\hline Negative & 5 & 8 & 0.481 & 7 & 6 & 1.000 & 11 & 2 & 0.671 & & & & & & \\
\hline Positive & 11 & 9 & & 11 & 9 & & 14 & 5 & & & & & & & \\
\hline \multicolumn{16}{|l|}{ p53 IHC } \\
\hline Negative & 14 & 12 & 0.398 & 14 & 12 & 1.000 & 21 & 4 & 0.157 & & & & & & \\
\hline Positive & 2 & 5 & & 4 & 3 & & 4 & 3 & & & & & & & \\
\hline
\end{tabular}

${ }^{*} p<0.05 ; \mathrm{P}$ : positive; $\mathrm{N}$ : negative. 
(LSAB System, DakoCytomation, Carpinteria, CA, USA) was used for detection with diaminobenzidine (DAB) as the chromogen. The following primary antibodies were used: mouse monoclonal antibodies directed against MYC (dilution 1:150; sc-40, Santa Cruz Biotechnology, Santa Cruz, CA, USA and clone 9E10, Zymed ${ }^{\circ}$, San Francisco, CA, USA), FBXW7 (dilution 1:50, Abnova Corp., Taipei City, Taiwan), and p53 (dilution 1:50; DakoCytomation, Carpinteria, CA, USA). Positive protein expression was defined as clear nuclear staining in more than $10 \%$ of the cells.

\section{Migration and invasion assay}

Migration and invasion assays were carried out in a modified Boyden chamber with filter inserts $(8-\mu \mathrm{m}$ pores) for 12-well plates (BD Biosciences, San Jose, CA, USA). To assess invasion, filters were coated with $10 \mu \mathrm{l}$ of Matrigel (10-13 mg/ml) (BD Biosciences, San Jose, CA, USA) while on ice. Cells $\left(2 \times 10^{5}\right)$ were plated into the upper chamber in $1 \mathrm{ml}$ of RPMI without FBS. The lower chamber was filled with $1.5 \mathrm{ml}$ of RPMI with FBS. After $48 \mathrm{~h}$ in culture, cells were fixed with $4 \%$ paraformaldehyde and post-fixed with $0.2 \%$ crystal violet in $20 \%$ methanol. Cells on the upper side of the filter, including those in the Matrigel, were removed with a cotton swab. Invading cells (on the lower side of the filter) were photographed and counted. Experiments were performed in triplicate.

\section{Immunofluorescence}

Cells grown on glass coverslips were fixed with $1 \%$ paraformaldehyde in phosphate-buffered saline (PBS) for $10 \mathrm{~min}$, then permeabilized with $0.5 \%$ Triton X-100 (Sigma-Aldrich, St. Louis, MO, USA) in PBS for $15 \mathrm{~min}$ and blocked with $1 \%$ bovine serum albumin (BSA) in PBS. The cells were stained with mouse antibodies against MYC (diluted 1:50; Zymed', USA), p53 (diluted 1:50; DakoCytomation, Carpinteria, CA, USA), and FBXW7 (diluted 1:50; Abnova Corp., Taipei City, Taiwan). Primary antibodies were revealed using an antimouse Alexa-568-conjugated secondary antibody (Invitrogen). All incubations were carried out for $60 \mathrm{~min}$ at room temperature. Nuclei were stained with DAPI in Prolong anti-fade mounting medium (Invitrogen). Negative control samples were processed as described above except that primary antibodies were omitted and replaced with PBS alone.

\section{Western blotting}

Protein extraction from cells was performed according to standard procedures. Briefly, total protein was extracted from ACP02 and ACP03 cells using $50 \mathrm{mM}$ Tris- $\mathrm{HCl}$ buffer containing $100 \mathrm{mmol} / \mathrm{L} \mathrm{NaCl}, 50 \mathrm{mM} \mathrm{NaF}, 1 \mathrm{mM}$ $\mathrm{NaVO}_{4}, 0.5 \% \mathrm{NP}-40$, and complete protease inhibitor cocktail (Roche, Germany). Protein concentration was estimated using a Bradford assay (Sigma-Aldrich). About $30 \mu \mathrm{g}$ of total protein extract was loaded onto a $12 \%$ sodium dodecyl sulfate-polyacrylamide gel electrophoresis (SDS-PAGE) gel and electrophoresed. Resolved proteins were then transferred from the gel onto a nitrocellulose membrane. The membrane was blocked with 5\% nonfat milk in Tris-buffered saline containing 5\% Tween (SigmaAldrich, Sant Louis, MO, USA) and then incubated with mouse monoclonal anti-MYC (Santa Cruz Biotechnology), anti-FBXW7 (Abnova, Taipei City, Taiwan), anti-p53 (DakoCytomation, Carpinteria, CA, USA), and anti- $\beta$ actin (Sigma-Aldrich, Sant Louis, MO, USA) antibodies diluted 1:200, 1:100, 1:100, and 1:2,000, respectively. Subsequently, membranes were incubated with a 1:5,000 dilution of horseradish peroxidase (HRP)-conjugated sheep anti-mouse antibody (Amersham Biosciences, Piscataway, NJ, USA) for $1 \mathrm{~h}$ at room temperature. Proteins were visualized by enhanced chemiluminescence.

\section{Zymography}

ACP02 and ACP03 cells $\left(5 \times 10^{4}\right.$ of each) were plated and allowed to adhere and spread for at least $8 \mathrm{~h}$. Adherent cells were washed three times with PBS, and the culture medium was replaced with serum-free medium for $24 \mathrm{~h}$. The activity of MMP2 and MMP9 in the conditioned medium was assessed by zymography. Conditioned medium was collected, concentrated (Microcon $30 \mathrm{~K}$, Merck Millipore, Darmstadt, Germany) and resuspended in SDS-PAGE sample buffer (without $\beta$ mercaptoethanol). The remaining cells were lysed and the protein concentration was estimated using a BCA assay (Thermo Scientific Pierce, Rockford, IL, USA). A total of $1 \mu \mathrm{g}$ of protein from each conditioned medium was separated on $10 \%$ polyacrylamide gels containing $0.2 \%$ gelatin. After electrophoresis, the gels were washed in $2.5 \%$ Triton $\mathrm{X}-100$ for $30 \mathrm{~min}$, then equilibrated in $10 \mathrm{mM}$ Tris $(\mathrm{pH} 8.0)$ and incubated at $37^{\circ} \mathrm{C}$ for $16-24 \mathrm{~h}$ in a development buffer containing $50 \mathrm{mM}$ Tris (pH 8.0), $5 \mathrm{mM} \mathrm{CaCl}_{2}$, and $0.02 \% \mathrm{NaN}_{3}$. The gels were stained with 0.2\% Coomassie blue R250 (GE Amersham, Piscataway, NJ, USA) and destained with 1:1 acetic acid/ methanol solution. Experiments were performed in triplicate. Zymographic bands, which are indicative of MMP activity, were quantified by scanning densitometry.

\section{Statistical analyses}

The normality of variable distributions was determined using the Shapiro-Wilk test. Associations between $M Y C$, $F B X W 7$, and TP53 copy number variation, mRNA levels, protein expression, clinicopathological features, and cell invasion and migration capability were analyzed using the chi-square $\left(x^{2}\right)$ and Mann-Whitney tests. Correlation between expression of the different target mRNAs 
was determined using Spearman's test, in which a value below 0.3 indicated a weak correlation, 0.3-0.7 indicated a medium correlation, and values above 0.7 indicated a strong correlation. Data are shown as the median and interquartile range; $\mathrm{p}$ values less than 0.05 were considered significant.

\section{Results}

Gastric tumor specimens showed amplification of $M Y C$ and deletion of FBXW7 and TP53

Three or more copies of MYC were found in 51.5\% (17/ $33)$ of gastric tumor cells. In contrast, $45.5 \%(15 / 33)$ and $21.2 \%(7 / 33)$ of gastric tumor cells contained only one copy of $F B X W 7$ and TP53, respectively.

The association between clinicopathological features and MYC, FBXW7, and TP53 copy number is summarized in Table 1. One gastric tumor that contained three copies of TP53 was excluded from the chi-square analysis. No association was found between copy number variation of the genes studied and clinicopathological features.

\section{MYC mRNA expression was higher in tumors than in non-neoplastic specimens, whereas FBXW7 and TP53 mRNA expression was lower in tumor specimens}

The expression level of MYC mRNA ( $2.01 \pm 1.72$ fold change) in tumor tissue samples was significantly higher than in non-neoplastic tissue $(\mathrm{p}=0.0002)$, whereas the expression level of $F B X W 7$ mRNA $(0.53 \pm 0.40$ fold change) and TP53 mRNA ( $0.84 \pm 0.55$ fold change) in tumor tissue specimens was significantly lower than in non-neoplastic tissue ( $\mathrm{p}<0.0001$ and $\mathrm{p}=0.0011$, respectively). We did not find a significant correlation between $M Y C, F B X W 7$, and TP53 mRNA expression $(\mathrm{MYCl}$ FBXW7 mRNA $\mathrm{r}=-0.3464, \mathrm{p}=0.0562 ; \quad M Y C / T P 53$ mRNA $\mathrm{r}=0.0950, \mathrm{p}=0.6113 ; \quad F B X W 7 / T P 53$ mRNA $\mathrm{r}=-0.0745, \mathrm{p}=0.4747)$. Thus, only a tendency toward correlation between an increase in $M Y C$ mRNA expression and a decrease in $F B X W 7$ mRNA expression was detected.

Table 2 summarizes the associations between various clinicopathological features and the RQ of $M Y C, F B X W 7$, and TP53 mRNA expression in tumor and paired nonneoplastic specimens. An increase in $M Y C$ mRNA level was associated with the presence of lymph node metastasis $(\mathrm{p}=0.016)$ and GC tumor stage III-IV $(\mathrm{p}=0.036)$. A significant reduction in $F B X W 7$ mRNA level was also associated with the presence lymph node metastasis $(\mathrm{p}=0.015)$ and tumor stage III-IV $(\mathrm{p}=0.008)$.

\section{Nuclear MYC protein staining is associated with intestinal-type GC}

Positive staining for nuclear MYC and p53 was found in $64.5 \%(20 / 31)$ and $19.4 \%(6 / 31)$ of GC samples, respectively (Figure 1). No positivity was found for FBXW7. Table 1 summarizes the clinicopathological features and MYC and p53 immunostaining results. Expression of MYC was more frequent in intestinal-type than diffuse-type GC $(\mathrm{p}=0.007)$. Furthermore, MYC immunostaining was associated with increased $M Y C$ mRNA level $(p=0.0022)$. No association was found between p53 immunostaining and clinicopathological characteristics, TP53 copy number, or TP53 mRNA expression.

\section{Comparison of ACPO2 and ACP03 cell lines}

Both ACP02 and ACP03 cells contained three MYC copies and only one FBXW7 copy. The number of TP53 copies was undetermined in both cell lines. Compared with mRNA expression in ACP03 cells, ACP02 cells expressed a higher level of $M Y C$ (1.34-fold) and lower levels of FBXW7 and TP53 mRNA (0.62- and 0.73-fold, respectively).

Western blot analyses revealed that MYC expression was significantly higher in ACP02 cells than ACP03 cells $(p=0.048)$. Moreover, FBXW7 expression was significantly lower in ACP02 cells than ACP03 cells $(\mathrm{p}=0.049)$. However, there was no significant difference in $\mathrm{p} 53$ expression between the cell lines $(\mathrm{p}=0.077)$ (Figure 2A-B).

Immunofluorescence analysis of both proteins showed a punctiform pattern of labeling, supporting the Western blot results showing an increase in MYC and reduction in FBXW7 expression in ACP02 cells compared with ACP03 (Figure 2). Matrigel invasion assay results showed that ACP02 cells were more invasive than ACP03 cells $(p=0.001)$. Migration assay results showed that fewer ACP02 cells migrated compared with ACP03 cells $(\mathrm{p}=0.0028)$ (Figure 2C-D).

Both ACP02 and ACP03 cells presented four gelatinase activity bands: MMP-9 latent $(92 \mathrm{kDa})$, MMP-9 active (88 kDa), MMP-2 latent (72 kDa), and MMP-2 active $(66 \mathrm{kDa})$ (Figure 3). We found no significant differences in MMP-9 latent $(\mathrm{p}=0.9788)$, MMP-2 active $(\mathrm{p}=0.7848)$, and MMP-2 latent $(\mathrm{p}=0.1678)$ between ACP02 and ACP03 cells. However, significant differences were found between ACP02 and ACP03 cells with respect to MMP-9 active $(\mathrm{p}=0.0182)$.

\section{Discussion}

In the current study, we observed that MYC mRNA expression was increased in GC samples compared with corresponding non-neoplastic samples. In addition, to our knowledge, this is the first study to report an association between increased MYC mRNA expression and the presence of lymph node metastasis and CG stage III-IV, reinforcing the idea that MYC deregulation is a strong factor for malignancy in GC. 
Table 2 MYC, FBXW7 and TP53 mRNA expression levels and clinicopathological factors of 33 gastric cancer patients

\begin{tabular}{|c|c|c|c|c|c|c|c|}
\hline & n (\%) & MYC & $p$-value & FBXW7 & $p$-value & TP53 & $p$-value \\
\hline & & Median \pm IQR & & Median \pm IQR & & Median \pm IQR & \\
\hline \multicolumn{8}{|c|}{ Age $(y)($ mean \pm SD) } \\
\hline$>50(65.3 \pm 9.1)$ & $19(57.6 \%)$ & $2.04 \pm 1.35$ & 0.8873 & $0.55 \pm 0.37$ & 0.9247 & $0.86 \pm 0.62$ & 0.7409 \\
\hline$\leq 50(42.1 \pm 8.2)$ & $14(42.4 \%)$ & $1.44 \pm 4.88$ & & $0.53 \pm 0.50$ & & $0.94 \pm 1.65$ & \\
\hline \multicolumn{8}{|l|}{ Gender } \\
\hline Male & $15(45.5 \%)$ & $2.01 \pm 1.01$ & 0.4065 & $0.53 \pm 0.22$ & 0.6353 & $0.89 \pm 0.58$ & 0.8125 \\
\hline Female & $18(54.5 \%)$ & $1.67 \pm 2.03$ & & $0.56 \pm 0.56$ & & $0.87 \pm 0.69$ & \\
\hline \multicolumn{8}{|l|}{ Histopathology } \\
\hline Intestinal & $22(66.7 \%)$ & $2.06 \pm 0.99$ & 0.3525 & $0.53 \pm 0.16$ & 0.1391 & $0.81 \pm 0.78$ & 0.3311 \\
\hline Diffuse & $11(33.3 \%)$ & $1.40 \pm 2.32$ & & $0.77 \pm 0.74$ & & $0.94 \pm 0.38$ & \\
\hline \multicolumn{8}{|c|}{ Depth of tumor invasion } \\
\hline $\mathrm{T} 1$ & $6(18.2 \%)$ & $0.89 \pm 0.47$ & 0.0857 & $0.88 \pm 0.58$ & 0.0678 & $0.85 \pm 0.15$ & 0.7069 \\
\hline $\mathrm{T} 2-\mathrm{T} 4$ & $27(81.8 \%)$ & $2.08 \pm 1.42$ & & $0.53 \pm 0.43$ & & $0.91 \pm 0.79$ & \\
\hline \multicolumn{8}{|c|}{ Lymph node metastasis } \\
\hline Absent & $13(39.4 \%)$ & $0.98 \pm 1.09$ & $0.0225^{*}$ & $0.68 \pm 0.36$ & $0.0238^{*}$ & $0.84 \pm 0.44$ & 0.6121 \\
\hline Present & $20(60.6 \%)$ & $2.10 \pm 2.20$ & & $0.46 \pm 0.38$ & & $0.94 \pm 0.79$ & \\
\hline \multicolumn{8}{|l|}{ Stage } \\
\hline$|-| \mid$ & $18(54.5 \%)$ & $1.39 \pm 1.23$ & $0.0362^{*}$ & $0.57 \pm 0.38$ & $0.0380^{*}$ & $0.83 \pm 0.55$ & $0.0892^{\dagger}$ \\
\hline III-IV & 15 (45.5\%) & $2.41 \pm 2.79$ & & $0.34 \pm 0.45$ & & $0.96 \pm 1.19$ & \\
\hline \multicolumn{8}{|l|}{ MYC IHC } \\
\hline Positive & $20(60.6 \%)$ & $2.18 \pm 1.59$ & $0.0022^{*}$ & $0.53 \pm 0.32$ & 0.4090 & $0.81 \pm 0.57$ & 0.1372 \\
\hline Negative & 13 (39.4\%) & $0.89 \pm 0.85$ & & $0.58 \pm 0.53$ & & $0.99 \pm 0.90$ & \\
\hline \multicolumn{8}{|l|}{ p53 IHC } \\
\hline Positive & 7 (21.2\%) & $4.25 \pm 6.53$ & 0.0891 & $0.64 \pm 0.68$ & 0.9203 & $1.06 \pm 0.83$ & 0.2937 \\
\hline Negative & $26(78.8 \%)$ & $2.00 \pm 1.44$ & & $0.55 \pm 0.35$ & & $0.87 \pm 0.60$ & \\
\hline
\end{tabular}

${ }^{*} p<0.05$; IQR: interquartile range.

Adams et al. [20] and Leder et al. [21] demonstrated that $M Y C$ mRNA expression deregulation can promote the development of cancer in transgenic mouse models. The increase in $M Y C$ mRNA level in human cancers may result from both direct and indirect mechanisms, which could have several explanations. First, $M Y C$ amplification is the most common mechanism of $M Y C$ deregulation in GC [5]. This mechanism leads to increased production of oncogenic products in quantities that exceed the transcriptional capacity of a normal double copy gene. Here, we observed three or more $M Y C$ gene copies in $51.5 \%$ of gastric tumors specimens. Previous studies from our group also showed that $M Y C$ amplification or trisomy of chromosome 8, on which $M Y C$ is located, was present in all GC samples examined from individuals in Northern Brazil, as well as in GC cell lines established by our group from tumors of Brazilian patients [18,22-27]. The presence of $M Y C$ amplification has also been reported in plasma samples from individuals with GC [28]. However, no direct association between $M Y C$ copy number variation and mRNA expression was detected in the present study.

Second, the increase in $M Y C$ mRNA expression may result from consistent recombination between the immunoglobulin (Ig) locus and the MYC oncogene. This phenomenon is frequently described in Burkitt's lymphoma and is associated with a longer half-life of $M Y C$ mRNA in affected cells [29]. Previously, our research group observed $M Y C$ insertions in diffuse-type GC mainly into chromosomes that are mapped to genes of immunoglobulins (chromosomes 2, 14, and 22) [26]. Thus, chromosomal translocations involving the $M Y C$ locus (8q24) in diffuse-type CG in individuals from Northern Brazil might also reflect an increase in $M Y C$ mRNA level.

Immunohistochemistry (IHC) analysis revealed that MYC expression is more frequently found in intestinaltype GC than diffuse-type GC specimens. These alterations could lead to an abnormal MYC protein that is not recognized by either of the antibodies used in the 


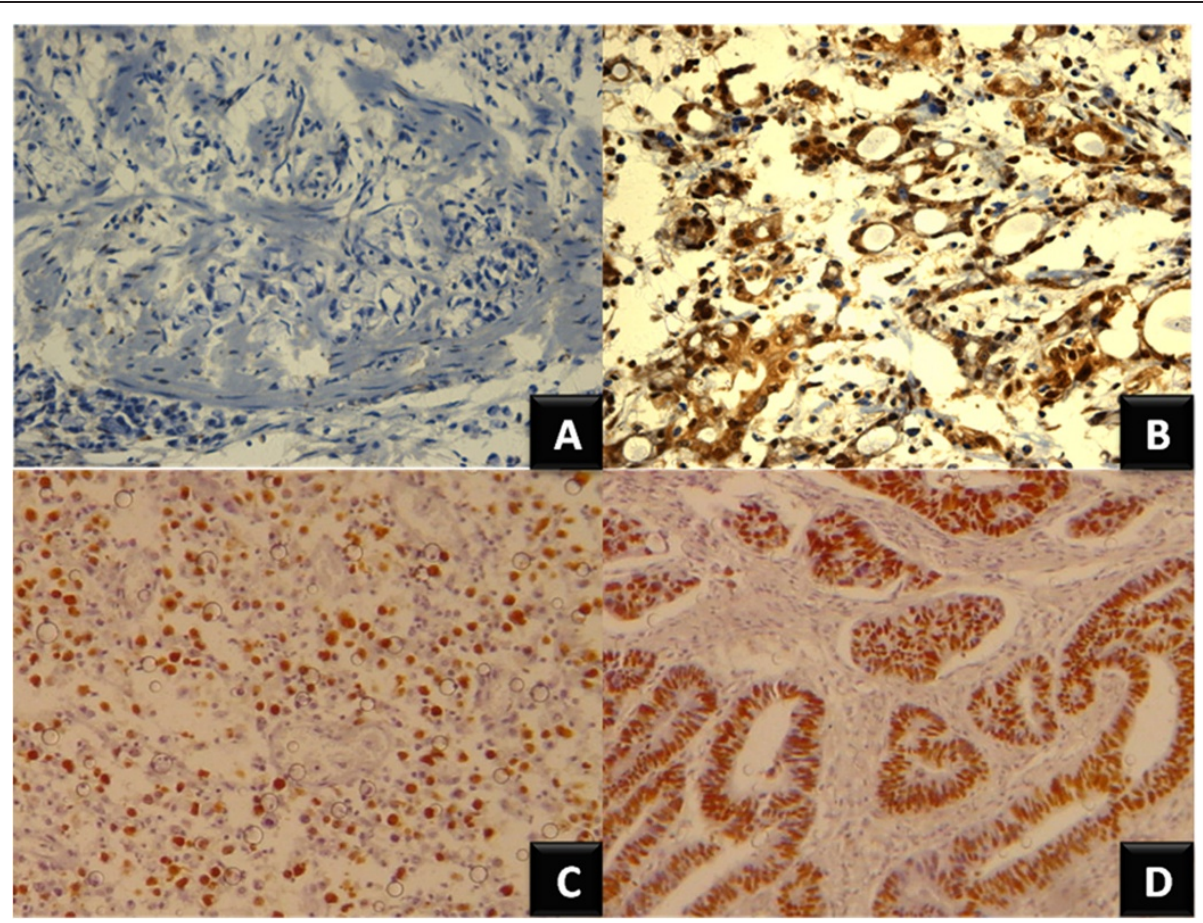

Figure 1 Immunohistochemical analysis of MYC and p53 protein expression in GC. (A) Negative MYC immunostaining in diffuse-type GC; (B) MYC immune positivity in intestinal-type GC; (C) Positive p53 immunostaining in diffuse-type GC; (D) p53 immune positivity in intestinal-type GC (magnification $\times 40$ ).

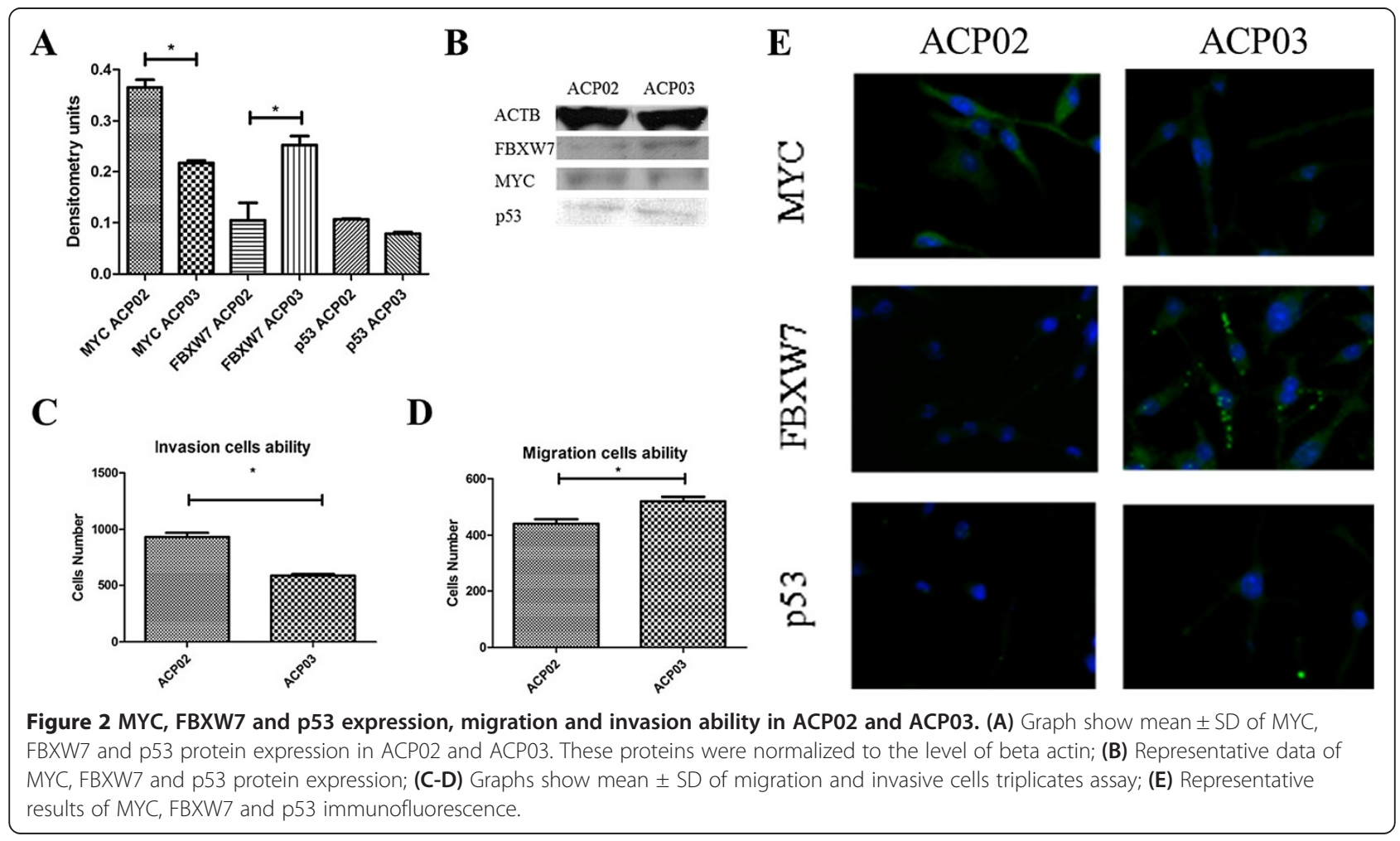




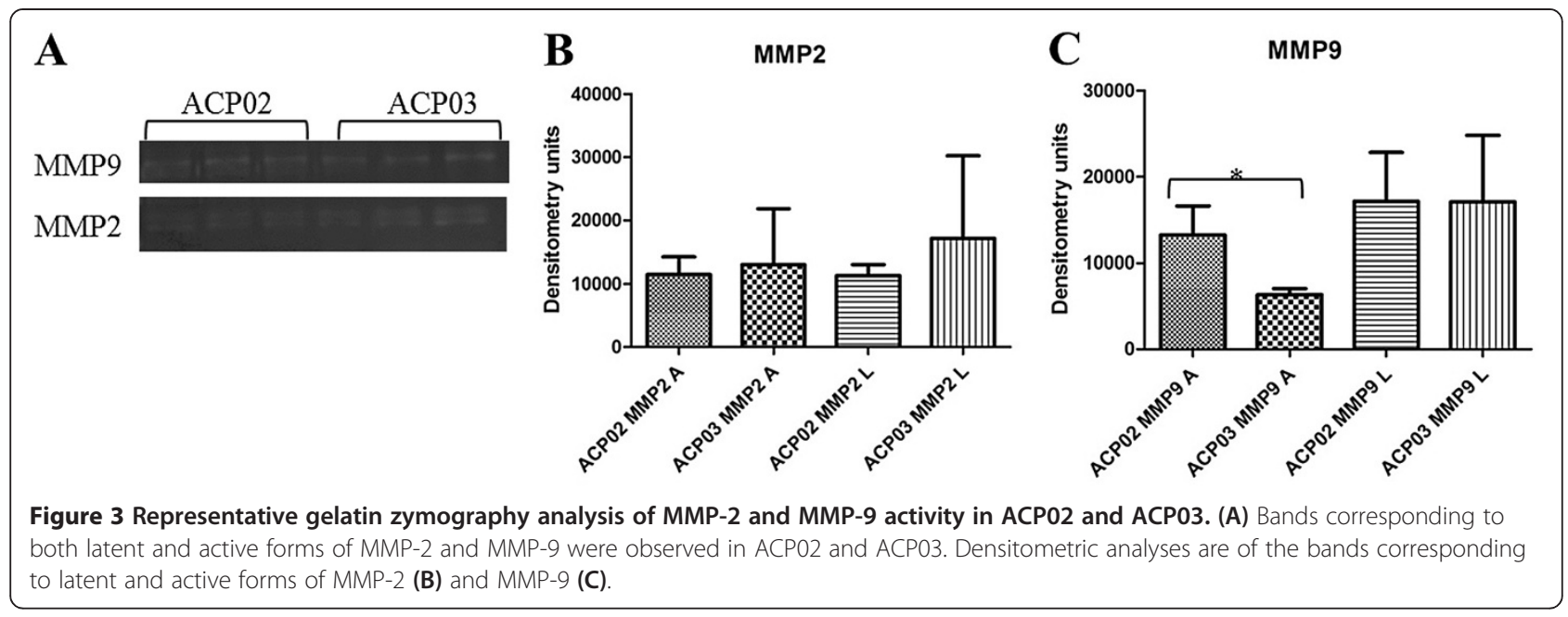

present study. Moreover, we observed an association between $M Y C$ mRNA expression level and MYC staining. Furthermore, posttranscriptional mechanisms control MYC stability [6,30]. MYC deregulation has been associated with loss of $F B X W 7$, a haploinsufficient tumor suppressor gene. In general, $F B X W 7$ loss may be caused by loss of heterozygosity $(\mathrm{LOH})$ and mutation [30]. The loss at $4 \mathrm{q}$, the $F B X W 7$ locus, is a recurring chromosomal alterations in GC [31,32], and $F B X W 7$ mutations have been found in 3.7-6\% of gastric tumors [12].

In the present study, we observed only one copy of the $F B X W 7$ gene in $45.16 \%$ of the gastric tumors studied. Interestingly, $F B X W 7$ mRNA expression in GC samples is markedly decreased in comparison with corresponding non-neoplastic tissue. In addition, $F B X W 7$ mRNA expression deregulation was associated with the presence of lymph node metastasis and GC stage III-IV, as was also observed with $M Y C$ mRNA. These findings corroborate the work of Yokobori el al. [13], which also showed an association between reduced $F B X W 7$ mRNA expression and lymph node metastasis that contributes to the malignant potential of GC cells and results in poor prognosis. Moreover, we observed that the expression of $M Y C$ and $F B X W 7$ mRNA tended to be inversely correlated in the present study.

Several studies showed that $M Y C$ inactivation suppresses tumors in animals, suggesting that $M Y C$ may be a molecular target in cancer treatment [33-35]. Alternatively, Soucek et al. [36] proposed that FBXW7 might facilitate "tumor dormancy therapy". Thus, MYC degradation by FBXW7 may not only induce a state of tumor dormancy but could also have an anti-tumor effect. Normally, MYC accumulation resulting from FBXW7 loss or another mechanism of MYC deregulation induces p53-dependent apoptosis via MDM2 degradation. The inactivation of both FBXW7 and p53 promotes MYC accumulation and inhibits p53-dependent apoptosis via
MDM2 activation, which may in turn induce cell proliferation $[37,38]$.

In this study, we found that $21.2 \%$ of the gastric tumors examined had one copy of the TP53 gene and also found a substantial decrease in TP53 mRNA level in GC tissues compared with paired non-neoplastic gastric tissue samples. Loss of p53 function could be caused primarily by $\mathrm{LOH}$ and mutations. TP53 mutations in somatic cells are observed in about $50 \%$ of human cancers, but the frequency and type of mutation varies from one tumor to another and can be exchange of sense, nonsense, deletion, insertion, or splicing mutations $[39,40]$. In CG, the rate of mutations in this gene is 18-58\% [41-43]. Some studies have shown that most missense mutations in TP53 cause changes in the conformation of the protein, thereby prolonging its halflife and leading to accumulation in the nucleus of neoplastic cells. This accumulation can be detected by IHC in about $19-29 \%$ of GC tumors [44]. Here, we observed p53 immunostaining in $19.4 \%$ (6/31) of GC samples. This finding was consistent with earlier studies by our group that described LOH of TP53 and deletion of $17 p$ as frequent alterations in GC cell lines and primary gastric tumors from individuals in Northern Brazil $[27,45]$. The $\mathrm{LOH}$ may be related to the reduction of TP53 mRNA expression observed in some of our GC samples. However, no association was found between this protein, TP53 mRNA level, copy number, or clinicopathological features. The lack of association between $M Y C, F B X W 7$, and TP53 copy number variation and mRNA and protein expression observed in this study highlights the complex relationship between gene copy number, mRNA expression, and protein stability.

In our previous cytogenetic study using fluorescence in situ hybridization (FISH), we described gains in $M Y C$ copies and deletions in TP53 in ACP02 and ACP03 gastric adenocarcinoma cell lines, thus corroborating the 
present results obtained using real-time qPCR [27]. Both alterations were observed in the primary tumors from which these cell lines were established. Since ACP02 and ACP03 cells present alterations similar to those of gastric tumors, these cell lines may be useful as tools for experimental modeling of gastric carcinogenesis and may enhance understanding of the genetic basis underlying GC behavior and treatment and perhaps may change the landscape of GC.

In the present study, we also observed increased $M Y C$ and reduced FBXW7 mRNA and protein expression in ACP02 cells compared with ACP03 cells. Furthermore, ACP02 cells were more invasive than ACP03 cells. On the other hand, ACP03 cells had a higher migration capability than ACP02 cells. Thus, despite the ability to migrate, ACP03 cells probably do not have efficient invasive machinery such as active proteases necessary to degrade the substrate. These findings are in agreement with observations in gastric tumors and reinforce the hypothesis that deregulation of MYC and FBXW7 is crucial for the invasive ability of GC cells. This result encouraged us to investigate the MMP-2 and MMP-9 activities of cells using zymography. The MMPs are synthesized as latent enzymes and later activated via proteolytic cleavage by themselves or other proteins in the intracellular space. Both proteases are synthesized predominantly by stromal cells rather than cancer cells and both contribute to cancer progression [46]. Our zymography analysis revealed no significant differences in the activity of MMP2 between ACP02 and ACP03 cells. Additionally, MMP-9 was more active in ACP02 than ACP03 cells. Studies have shown that high levels of MMP-2 and/or MMP-9 are significantly correlated with $\mathrm{GC}$ invasion and are associated with poor prognosis $[47,48]$. Sampieri et al. [49] showed that MMP-9 expression is enhanced in GC mucosa compared to nonneoplastic mucosa and that gelatinase activity differs significantly between cancerous and normal tissue.

\section{Conclusions}

In conclusion, our findings show that $F B X W 7$ and $M Y C$ mRNA levels reflect the potential for aggressive biologic behavior of gastric tumors and may be used as indicators of poor prognosis in GC patients. Furthermore, MYC can be a potential biomarker for use in development of new targets for GC therapy.

\section{Competing interests}

The authors declare that they have no competing interests.

\section{Authors' contributions}

DQC, VMF, ASK, MACS, AKRS and RRB participated in conception and design of study. DQC, VMF, SD participated in acquisition and performed the analysis of data. DQC, VMF, MFL, SD, CRTS performed interpretation of data. $D Q C, V M F, R M, P P A$ and RRB involved in drafting the manuscript. All authors read and approved the final manuscript.

\section{Acknowledgments}

This study was supported by Conselho Nacional de Desenvolvimento Científico e Tecnológico (CNPq) as grants and fellowship awards. RRB, MACS, RM, ASK and AKRS have research grants from CNPq. DQC, MFL and CRTS has a fellowship granted by CNPq and Fundação de Amparo a Pesquisa do Estado de São Paulo (FAPESP).

\section{Author details}

'Laboratório de Citogenética Humana, Instituto de Ciências Biológicas, Universidade Federal do Pará, Belém, PA, Brasil. ²Disciplina de Genética, Departamento de Morfologia e Genética, Escola Paulista de Medicina, Universidade Federal de São Paulo, Rua Botucatu 740, CEP 04023-900, São Paulo, SP, Brazil. ${ }^{3}$ Departamento de Biologia Celular e do Desenvolvimento, Instituto de Ciências Biomédicas, Universidade de São Paulo, São Paulo, SP, Brasil. "Laboratorio de Imunoistoquímica, Serviço de Anatomia Patológica, Faculdade de Medicina, Hospital Universitário João de Barros Barreto, Universidade Federal do Pará, Belém, PA, Brasil. ${ }^{5}$ Serviço de Cirurgia Hospital Universitário João de Barros Barreto, Universidade Federal do Pará, Belém, PA, Brasil. '́Laboratório de Genética Humana, Instituto de Ciências Biológicas, Universidade Federal do Pará, Belém, PA, Brasil.

Received: 17 January 2013 Accepted: 10 September 2013 Published: 23 September 2013

\section{References}

1. Brenner $\mathrm{H}$, Rothenbacher $\mathrm{D}$, Arndt $\mathrm{V}$ : Epidemiology of stomach cancer. Methods in molecular biology (Clifton, NJ 2009, 472:467-477.

2. Dicken BJ, Bigam DL, Cass C, Mackey JR, Joy AA, Hamilton SM: Gastric adenocarcinoma: review and considerations for future directions. Ann Surg 2005, 241(1):27-39.

3. Smith MG, Hold GL, Tahara E, El-Omar EM: Cellular and molecular aspects of gastric cancer. World J Gastroenterol 2006, 12(19):2979-2990.

4. Dang CV, O'Donnell KA, Zeller Kl, Nguyen T, Osthus RC, Li F: The c-Myc target gene network. Semin Cancer Biol 2006, 16(4):253-264.

5. Calcagno DQ, Leal MF, Assumpcao PP, Smith MA, Burbano RR: MYC and gastric adenocarcinoma carcinogenesis. World J Gastroenterol 2008, 14(39):5962-5968.

6. Vervoorts J, Luscher-Firzlaff J, Luscher B: The ins and outs of MYC regulation by posttranslational mechanisms. J Biol Chem 2006, 281(46):34725-34729.

7. Bashir T, Pagano M: Aberrant ubiquitin-mediated proteolysis of cell cycle regulatory proteins and oncogenesis. Adv Cancer Res 2003, 88:101-144.

8. Nakayama Kl, Nakayama K: Regulation of the cell cycle by SCF-type ubiquitin ligases. Seminars in cell \& developmental biology 2005, 16(3):323-333.

9. Onoyama I, Nakayama KI: Fbxw7 in cell cycle exit and stem cell maintenance: insight from gene-targeted mice. Cell cycle (Georgetown, Tex 2008, 7(21):3307-3313.

10. Mao JH, Perez-Losada J, Wu D, Delrosario R, Tsunematsu R, Nakayama Kl, Brown K, Bryson S, Balmain A: Fbxw7/Cdc4 is a p53-dependent, haploinsufficient tumour suppressor gene. Nature 2004, 432(7018):775-779.

11. Welcker M, Clurman BE: Fbw7/hCDC4 dimerization regulates its substrate interactions. Cell division 2007, 2:7.

12. Akhoondi S, Sun D, von der Lehr N, Apostolidou S, Klotz K, Maljukova A, Cepeda D, Fiegl H, Dafou D, Marth C, et al: FBXW7/hCDC4 is a general tumor suppressor in human cancer. Cancer Res 2007, 67(19):9006-9012.

13. Yokobori T, Mimori K, Iwatsuki M, Ishii H, Onoyama I, Fukagawa T, Kuwano H, Nakayama Kl, Mori M: p53-Altered FBXW7 expression determines poor prognosis in gastric cancer cases. Cancer Res 2009, 69(9):3788-3794.

14. Kountouras J, Zavos C, Chatzopoulos D: New concepts of molecular biology on gastric carcinogenesis. Hepatogastroenterology 2005, 52(64):1305-1312.

15. Lauren P: The Two Histological Main Types of Gastric Carcinoma: Diffuse and So- Called Intestinal-Type Carcinoma. an Attempt at a Histo-Clinical Classification. Acta pathologica et microbiologica Scandinavica 1965, 64:31-49.

16. Clayton CL, Kleanthous H, Morgan DD, Puckey L, Tabaqchali S: Rapid fingerprinting of Helicobacter pylori by polymerase chain reaction and restriction fragment length polymorphism analysis. J Clin Microbiol 1993, 31:1420-1425. 
17. Covacci A, Falkow S, Berg DE, Rappuoli R: Did the inheritance of a pathogenicity island modify the virulence of Helicobacter pylori? Trends Microbiol 1997, 5:205-208.

18. Leal MF, Martins do Nascimento JL, da Silva CE, Vita Lamarao MF, Calcagno DQ, Khayat AS, Assumpcao PP, Cabral IR, de Arruda Cardoso Smith M, Burbano RR: Establishment and conventional cytogenetic characterization of three gastric cancer cell lines. Cancer Genet Cytogenet 2009, 195(1):85-91.

19. Livak KJ, Schmittgen TD: Analysis of relative gene expression data using real-timequantitative PCR and the 2(-Delta Delta C(T)) Method. Methods 2001, 25:402-408

20. Adams JM, Harris AW, Pinkert CA, Corcoran LM, Alexander WS, Cory S, Palmiter RD, Brinster RL: The c-myc oncogene driven by immunoglobulin enhancers induces lymphoid malignancy in transgenic mice. Nature 1985, 318:533-538

21. Leder A, Pattengale PK, Kuo A, Stewart TA, Leder P: Consequences of widespread deregulation of the c-myc gene in transgenic mice: multiple neoplasms and normal development. Cell 1986, 45:485-495.

22. Calcagno DQ, Leal MF, Taken SS, Assumpcao PP, Demachki S, Smith Mde A, Burbano RR: Aneuploidy of chromosome 8 and C-MYC amplification in individuals from northern Brazil with gastric adenocarcinoma. Anticancer Res 2005, 25(6B):4069-4074.

23. Calcagno DQ, Leal MF, Seabra AD, Khayat AS, Chen ES, Demachki $S$, Assumpcao PP, Faria MH, Rabenhorst SH, Ferreira MV, et al: Interrelationship between chromosome 8 aneuploidy, C-MYC amplification and increased expression in individuals from northern Brazil with gastric adenocarcinoma. World J Gastroenterol 2006, 12(38):6207-6211.

24. Burbano RR, Assumpcao PP, Leal MF, Calcagno DQ, Guimaraes AC, Khayat AS, Takeno SS, Chen ES, De Arruda Cardoso Smith M: C-MYC locus amplification as metastasis predictor in intestinal-type gastric adenocarcinomas: CGH study in Brazil. Anticancer Res 2006, 26(4B):2909-2914.

25. Costa Raiol LC, Figueira Silva EC, Mendes da Fonseca D, Leal MF, Guimaraes AC, Calcagno DQ, Khayat AS, Assumpcao PP, de Arruda Cardoso Smith M, Burbano RR: Interrelationship between MYC gene numerical aberrations and protein expression in individuals from northern Brazil with early gastric adenocarcinoma. Cancer Genet Cytogenet 2008, 181(1):31-35.

26. Calcagno DQ, Guimaraes AC, Leal MF, Seabra AD, Khayat AS, Pontes TB, Assumpcao PP, De Arruda Cardoso Smith M, Burbano RR: MYC insertions in diffuse-type gastric adenocarcinoma. Anticancer Res 2009, 29(7):2479-2483

27. Leal MF, Calcagno DQ, Borges da Costa Jde F, Silva TC, Khayat AS, Chen ES, Assumpção PP, de Arruda Cardoso Smith M, Burbano RR: MYC, TP53, and chromosome 17 copy-number alterations in multiple gastric cancer cell lines and in their parental primary tumors. J Biomed Biotechnol 2011 2011:631268.

28. Park KU, Lee HE, Park do J, Jung EJ, Song J, Kim HH, Choe G, Kim WH, Lee HS: MYC quantitation in cell-free plasma DNA by real-time PCR for gastric cancer diagnosis. Clin Chem Lab Med 2009, 47(5):530-536.

29. Eick D, Piechaczyk M, Henglein B, Blanchard JM, Traub B, Kofler E, Wiest S, Lenoir GM, Bornkamm GW: Aberrant c-myc RNAs of Burkitt's lymphoma cells have longer half-lives. EMBO J 1985, 4(13B):3717-3725.

30. Payne SR, Kemp CJ: Tumor suppressor genetics. Carcinogenesis 2005, 26(12):2031-2045.

31. Takada H, Imoto I, Tsuda H, Sonoda I, Ichikura T, Mochizuki H, Okanoue T, Inazawa J: Screening of DNA copy-number aberrations in gastric cancer cell lines by array-based comparative genomic hybridization. Cancer science 2005, 96(2):100-110.

32. Panani AD: Cytogenetic and molecular aspects of gastric cancer: clinical implications. Cancer letters 2008, 266(2):99-115.

33. Shachaf CM, Kopelman AM, Arvanitis C, Karlsson A, Beer S, Mandl S, Bachmann MH, Borowsky AD, Ruebner B, Cardiff RD, et al: MYC inactivation uncovers pluripotent differentiation and tumour dormancy in hepatocellular cancer. Nature 2004, 431(7012):1112-1117.

34. Yu D, Dews M, Park A, Tobias JW, Thomas-Tikhonenko A: Inactivation of Myc in murine two-hit B lymphomas causes dormancy with elevated levels of interleukin 10 receptor and CD20: implications for adjuvant therapies. Cancer Res 2005, 65(12):5454-5461.

35. Shachaf CM, Felsher DW: Tumor dormancy and MYC inactivation: pushing cancer to the brink of normalcy. Cancer Res 2005, 65(11):4471-4474.
36. Soucek L, Whitfield J, Martins CP, Finch AJ, Murphy DJ, Sodir NM, Karnezis AN, Swigart LB, Nasi S, Evan Gl: Modelling Myc inhibition as a cancer therapy. Nature 2008, 455:679-683.

37. Zindy F, Eischen CM, Randle DH, Kamijo T, Cleveland JL, Sherr CJ, Rousse MF: Myc signaling via the ARF tumor suppressor regulates p53dependent apoptosis and immortalization. Genes \& development 1998 12:2424-2433

38. Pelengaris S, Khan M: The many faces of c-MYC. Arch Biochem Biophys 2003, 416:129-136.

39. Harris CC, Hollstein M: Clinical implications of the p53 tumor-suppressor gene. N Engl J Med 1993, 329(18):1318-1327.

40. Chang F, Syrjanen S, Syrjanen K: Implications of the p53 tumor-suppressor gene in clinical oncology. J Clin Oncol 1995, 13(4):1009-1022.

41. Renault B, van den Broek M, Fodde R, Wijnen J, Pellegata NS, Amadori D, Khan PM, Ranzani GN: Base transitions are the most frequent genetic changes at P53 in gastric cancer. Cancer Res 1993, 53(11):2614-2617.

42. Seruca R, David L, Castedo S, Veiga I, Borresen AL, Sobrinho-Simoes M: p53 alterations in gastric carcinoma: a study of 56 primary tumors and 204 nodal metastases. Cancer Genet Cytogenet 1994, 75(1):45-50.

43. Poremba C, Yandell DW, Mellin W, Schmid KW, Reers B, Bocker W, Dockhorn-Dworniczak B: Adenocarcinoma of the cardia in a young man: detection of somatic p53 mutation by immunohistochemistry and automated direct sequencing. Pathol Res Pract 1995, 191(10):1004-1009.

44. Hollstein M, Sidransky D, Vogelstein B, Harris CC: p53 mutations in human cancers. Science 1991, 253:49-53.

45. Khayat AS, Guimaraes AC, Calcagno DQ, Seabra AD, Lima EM, Leal MF, Faria MH, Rabenhorst SH, Assumpcao PP, Demachki S, et al: Interrelationship between TP53 gene deletion, protein expression and chromosome 17 aneusomy in gastric adenocarcinoma. BMC gastroenterology 2009, 9:55.

46. Kessenbrock K, Plaks V, Werb Z: Matrix metalloproteinases: regulators of the tumor microenvironment. Cell 2010, 14(1):52-67.

47. Kong L, Sun JW, Zhang CH: The expression of integrinalphanubeta6 and MMP-9 in gastric cancer and the correlation with clinicopathologic characteristic. Xi Bao Yu Fen Zi Mian Yi Xue Za Zhi 2011, 27(1):92-94.

48. Kubben FJ, et al: Matrix metalloproteinase-2 is a consistent prognostic factor in gastric cancer. Br J Cancer 2006, 94(7):1035-1040.

49. Sampieri $\mathrm{CL}$, et al: Expression of matrix metalloproteinases 2 and 9 in human gastric cancer and superficial gastritis. World J Gastroenterol 2010, 16(12):1500-1505.

doi:10.1186/1471-230X-13-141

Cite this article as: Calcagno et al:: MYC, FBXW7 and TP53 copy number variation and expression in Gastric Cancer. BMC Gastroenterology $201313: 141$

\section{Submit your next manuscript to BioMed Central and take full advantage of:}

- Convenient online submission

- Thorough peer review

- No space constraints or color figure charges

- Immediate publication on acceptance

- Inclusion in PubMed, CAS, Scopus and Google Scholar

- Research which is freely available for redistribution
C BioMed Central 